\title{
Obraz Huculszczyzny w listach Stanisława Vincenza
}

\author{
Olga Ciwkacz
}




\section{Olga Ciwkacz}

\section{Obraz Huculszczyzny w listach Stanisława Vincenza}

$\mathrm{K}$ orespondencja Stanisława i Ireny Vincenzów zbadana zostala tylko w dość niewielkim zakresie i wymaga odrębnego opracowania, ponieważ literatura polska, jak się wydaje, ma niewielı pisarzy o tak dużym dorobku epistolarnym. Jeśli kiedyś doczekany się takiego naukowego wydania listów Vincenza, to, naszym zdaniem, będą one odczytane nie tylko jako dokumenty do biografii pisarza, ale i jako część jego twórczości artystycznej, dzięki której bez wątpliwości lepiej zrozumiemy Vincenza nie tylko jako człowieka, ale i jako artystę.

Listów, które Vincenz otrzymywal lıb pisywał sam, jest dużo. Są one różnorodne pod względem tematycznym - mamy zatem listy oficjalne, żartobliwe, listy-propozycje, listy-pozdrowienia, listy-wspomnienia. Listy owe adresowane byly do różnych osób, a sama rodzina Vincenzów otrzymywała korespondencję ze wszystkich stron świata. W nicktórych z nich znaleźć można wspólne elementy - wspommienia o rodzinnej I Iuculszczyźnie. Nie będzie przesadą, jeśli ıżyje się stwierdzenia, iż właśnie obraz Huculszczyzny jest nieodlączną częścią Vincenzowskiej epistolografii. Stanie się to wręcz oczywistym, gdy uświadominy sobie, że najważniejszym utworem dla samego pisarza, .księgą jego życia”, byla powieść Na u'ysokicj połoninie, nad którą zresztą artysta pracowal, można by rzec, aż do śmierci.

Właśnie korespondencja pomaga zrozumieć, jak ważne dla Vincenza było napisanie tej książki, jak wiele czasu i sił poświęcal on tworzeniu na emigracji następnych części swojej tetralogii. W marcu 1953 roku w liście do Bazylego Przybyłowskiego pisze on:

Postanowilem w tym roku wreszcie skończyć drugi tom Połoniny, i całą wiosnę pracowalem nad nowymi rozdziałami, albo uzupehıiałem dawno już napisane, tak jak wynika z kompozycji, bo wstecz widzi się lepiej niż naprzód'.

' St. Vincenz do Bazylego Przybylowskiego, $2+$ marca 1953 (sygnl. 17 658/11). Wszystkic listy Stanislawa Vincenza i listy do niego cytuję za materialami archiwum Stanislawa i Ireny Vincenzów, znajdıjącymi siç w Dziale Rękopisów Biblioteki Zakladı Narodowego im. Ossolińskich we Wrocławiu. 
W tym liście harmonijnie połączona jest opowieść Vincenza o treści dalszych rozdziałów i swoista liryczna dygresja o dramatycznej sytuacji Polaków-emigrantów, wywołana właśnie wspomnieniami Huculszczyzny:

Widzisz Baziu, a teraz my wszyscy jesteśmy „11a czużyni”, i ,choć nas chwyta w swoje szpony to tempo „prędzej, prędzcj”, przyzwyczailiśmy się chętnie albo niechętnie, i może czasem nawet myślinny, że nie może być inaczej (...). A my zawsze jesteśmy przecież tam, gdzie nasze korzenie, to znaczy nad Czeremoszen i Waratynem².

26 czerwca 1966 roku w liście do dawnej przyjaciólki Konstancji Dolanowskiej, która w tym czasic mieszkała w Londynie, Vincenz pisze, że na obczyźnie dla niego

Jedyną (...) formą działalności może być litcratura, która zostawi może nawet kilku narodom obrazy wháciwych im symbolów. Huculszczyzna pasterska jako jedna z najtrwalszych reliktów federatywnej Polski wydała mi się jedynym, co mogę pozostawić z mego kraju, z mojej młodości, a nawet z dzieciństwa ${ }^{3}$.

Dlatego po trzynastu latach, które minęly od napisania cytowanego wyżej listu do Przybylowskiego, jego praca nad książką o Huculszczyźnie wciąż trwała. Można przypuścić, że to wlaśnie tęsknota za utraconą ojczyzną byla decydującą siłą jego dziahalności na emigracji, zwlaszcza w latach powojennych.

W listach do bliskich przyjaciól, podzielających jego myśl, Vincenz bardzo często opowiada o swych pomyslach, o źródlach, które już wybrał do kolejnych części swego utworu, o szczególach wątku i kompozycji następnych części powieści-eposu. Można powiedzieć, że epistolografia Vincenza żywi się tematami i motywani jego utworów artystycznych. Szczególnym elementem stylistycznym tych listów są , inkrustacje” z gwary huculskiej. Vincenz przeważnie wprowadza podobną „dekorację” w części końcowej listu lub jego na samo zakończenie:

Tymczasem Was wszystkich serdecznie pozdrawiam, niech braterski sztandar zaszumi nad Stobodą! „Kilko bude, Wasy'tku, twollo tourarystu'a? Tak jak w' naszych bukourinkach zelenoho tystu!" - Wasz stary';

Ściskam was czule, mówiąc po huculsku: daj Boże myrno, daj Boże zdoroueczko, zdorou'eriki buty $y^{3}$.

\footnotetext{
2Ibidem.

${ }^{3}$ St. Vincenz do Konstancji Dolanowskiej. 26 czerwea 1966 (sygn. 17 651/1I).

+ St. Vincenz do Prokopiwa, 7 maja 1966 (sygnt. 17 658/11).

${ }^{5}$ St. Vincenz do Gustawa i Krystyny Goldbergów. 20 lipca $196+$ (sygn. 17 651/II).
} 
Niekiedy pan Stanislaw zaznaczal, że jego pożegnania-pozdrowienia są wprost huculskie:

Pozwoli Pan, że pozdrowię Pana starym pozdrowienicm, które słychać między Czarnogorą, między Łysimą i wszędzie tam, gdzie nam bądź co bądź trochę lżej było oddychać, i ,Myrom, kobyste dizdaty, taj zdoroureriky by'y usi myli susidoniky!"'.

Nawet na pocztówkach z życzeniami świątecznymi Vincenz z miłością i łagodnym lıumorem wspomina strony ojczyste, swoich przyjaciót z micjscowości na I Iuculszczyźnie - Zabiego:

Nasi Kochani Żaby, Żabki i Żabeczki! Przyjmijcie od starych rodaków z nad Czeremoszu, chasydzko-huculskich, najserdeczniejsze życzenia szczęstliwych Świat Pejsachowych. Zdorourérki but)', ta daj Bo:之e my'rno!?

Zapraszając przyjaciól do siebie, Vincenz nie kusil ich urokiem Francji, ale tym właśnie, że przyroda La Combe przypomina ojczystą Huculszczyznę:

Może kiedyś razem pojedziemy w góry, które bądź co bądź przypominają nasze strony. Także zielcí, także i ptaki. Tylko takiego pięknego miasta jak Buczacz ze swym ratuszem nigdzie tutaj nie znaleźliśmy, jak dotychczass

Uciekając w maju 1940 roku z „sowieckiego raju”, Stanisław Vincenz zostawił cały swój majątek w Bystrzecu — dom, książki, meble. Lecz bezcenne byly dla niego materiały dotyczące historii, kultury i życia I Iuculszczyzny. Po latach Stanislaw Vincenz tak o tym napisze:

Co do zbiorów huculskich, to udalo nam się wynieść na plecach, podczas ucieczki na Węgry w roku 1940, najcenniejsze materiały, a mianowicie kilkaset fotografii, a także rękopiśmienne zbiory zapisane przez muie i przez moją żonę, pieśni, teksty zaklęć, opisy obyczajów, słowniczek huculski, a wreszcie, last not least, pelny spis nazwisk huculskich".

\footnotetext{
${ }^{6}$ St. Vincenz do Prokopiwa, 19 maja 1966 (sygn. 17 658/II).

${ }^{7}$ St. Vincenz do rodziny (Gertnerów w lzraclu. + kwiennia 1966 (pocztówka: sygn. 17 651/II). Vincenzowic jeszcze przed wojna poznali Gertnerów, którzy w Żabien prowadzili hotel turystyczny i restantację. Dlatego wlaśnic -- „żaby, żabki i żabeczki”.

${ }^{*}$ St. Vincenz do Gustawa Goldberga, 26 styczuia 1965 (sygnn. $17651 / 11$ ).

"St. Vincenz do Stanisława Paprockiego, 6 stycznia 1969) (sygn. 17 658/I1). Whaśnie te materialy dotyczące nazwisk huculskich stały się podstawą pracy doktorskicj syna pisarza, Andrzcja Vincenza.
} 
Nadzwyczaj interesująca była idea Polaków-emigrantów stworzenia w Ameryce Muzeum Polskiego. Stanisław Vincenz popieral ten projekt. W listach do Bazylego Przybyłowskiego dokkadnie omawia plany otwarcia podobnego ośrodka kulturalnego w Ameryce, w którym jego zdaniem powinny być przedstawione działy historii Polski, literatury i sztuki, i koniecznie etnografii („dział etnograficzny jest bardzo ważny”), podkreślając, że „do tego naturalnie należy Iuculszczyzna"|". Zalożenie podobnego muzeum Vincenz uważał za dobrą sprawę i polecal Przybyłowskiemu zwrócenie się, w sprawie poszukiwania eksponatów, do wszystkich Polaków, mieszkających w różnych krajach świata" ${ }^{11}$.

W 1966 rokı w Neapolu miano otworzyć nowoczesną i postępową pod względem metod oświaty i wychowania szkołę szwajcarską, w której zalożeniu brał udzial brat Stanislawa Vincenza - Kazimierz. Otwarcic miało być bardzo uroczyste. Interesujące, że i to wydarzenie nie moglo się odbyć bez akcentu huculskiego. Stanisław Vincenz z satysfakcją napisze w liście do Przybylowskich:

wlaśnie jestem zaproszony do otwarcia tej szkoły moja przemową, a mój brat Kazik obiecal nauczyć uczniów szwajcarsko-wlosko-angielskich, którzy także mają otworzyć szkolę za pomocą tańców huculskich.

Ale to „lączenie” się z Huculszczyzną nie powinno było być, zdaniem Vincenza, jednorazową akcją, lecz być kontynuowane w systemacie estetycznym i wychowawczym uczniów:

Ponadto na pamiątkę dawnych więzów w tejże szwajcarskiej szkole ma być zachowana tradycja huculskich tańców, jak przypuszczam, tańców świątecznych i magicznych z okresu Bożego Narodzenia, tzw. pljes (...).

Korespondencja Vincenza często ma coś wspólnego ze szczerą rozmową przyjaciół. Czytając te linijki, rozumiemy, ze Vincenz pisze dany list do przyjaciela, który tak jak on dobrze znat kraj huculski i pamiętał swoiste piękno huculskiego folkloru, mógł glębiej zrozumieć myśl Vincenza i zamieszczony w liście cytat z huculskiej kolędy:

Moze Ty, Baziu, pamiętasz że był tam taniec wybitnie magiczny, tzn. dążący

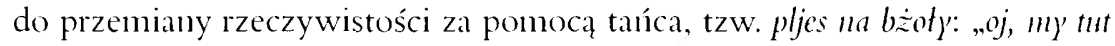
i't', oj, my tut pyty, oj, koby sy u'am bzoty roity!". Jak może pamiętasz, Baziu, taniec zaczyna się introdukcją kozy rogatej, która, skacząc, na tę samą melodię śpiewa: „Oj, dobryj u'ecze' do cei chat)! Czy pozu'otyte kozi ptesaty?", na co

\footnotetext{
1" St. Vincenz do Bazylego Przybylow'skicgo, 10 stycznia 1953 (sygn1. 17 658/II).

"Ibide'n.
} 
chór domowników odpowiada hucznie: „Oj, skaczi, skaczi, kozo-nebogo, nasijau' nasz pan pszenyci mmoho". I to whaśnic po wieczne czasy mieliby śpiewać, skacząc, uczniowie szwajcarskiej szkoly w Neapolu!?

Z pewnością trudno teraz wyobrazić sobie taki obraz: uczniowie z Neapolu śpiewający i tańczący pieśni huculskie. Ale dla Vincenza, który doskonale znał i cenil tradycyjną kulturę Hucułów, nauczanie kultury Huculszczyzny obok kultury starożytnych Greków bylo calkiem logiczne. Świadczą o tym stowa z listu do Przybylowskiego, w którym Vincenz opowiadał o próbie przeprowadzenia w Lozannie wieczoru pod tytutem Rizdu'o lunculskic, i wywodził, że magiczne obrzędy I Iucuków są bardzo bliskie do obrzędów dawnych Greków:

w starogreckiej religii kontakt z duszami, które opuścily nasz świat, byl przeważnie utrzymywany za pomocą symboli, szczególnie dobre nam znanego, a mianowicie przez kutię ${ }^{13}$

- zatem droga jego sercu Huculszczyzna i wiedza o niej nic będą zbędne także w szwajcarsko-włosko-angielskiej szkole.

Syn pisarza, Andrzej Vincenz, słusznie nazwał dom rodzinny w Slobodzie Rungurskiej, dworek Dziadka w Krzyworówni, swoistym „światem duchowym”, miniśrodowiskiem, które miało znaczny wplyw na ksztaltowanie się życiowej pozycji i światopoglądı pisarzalt. Sam Stanisław Vincenz stale podkreślał, że najlepszych cech ludzkich nauczył się wlaśnie od I Iuculów i zawsze wierzyl w prorocze stowa swojej niani Pałagny:

Tymozasem wiercie mi (...) bo od I Iucułów nauczyłem się być wiernym, tak jak moja stareńka kochana niania Pałagna, tym bardziej, że przepowiedziata mi niegdyś wielkie słowo, w które z miejsca uwierzylem. „Korotem budesz, donjkn!"

Niekiedy w listach calkiem dalekich od tematu huculskiego jest on wywoływany przez Vincenza jako swoisty wzorzec porządności czy humanizmu. Tak w dramatycznym liście do Bazylego Rogowskiego, w którym opowiada o chorobie i śmierci swej pierwszej żony Leny, Vincenz przeciwstawia naturalny humanizm luculskiej babki-znachorki bezduszności angielskich lekarzy:

\footnotetext{
12 St. Vincenz do Bazylego Przybylowskiego, 13 kwictnia 1960 (sygn. 17 658/11).

1.3 St. Vincenz do Bazylego Przybylowskiego, 8 stycznia 1967 (sygn. $17658 /$ II).

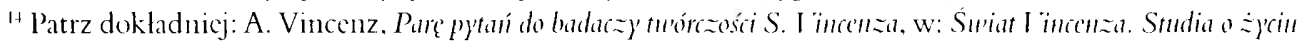
i túórzośi Stanistan'a I incenza (1888-1971). red. J. A. Choroszy, J. Kolbuszewski, Wroclaw 1992, s. 31-35.

${ }^{5}$ St. Vincenz do Konstancji Dolanowskicj. It lutego 1969 (sygn. 17 651/11).
} 
Ja sam jestem zasadniczym przeciwnikiem lekarzy i szpitali, chociaż oczywiście nie jestem doktrynerem, ale czekam od lekarza jednego: aby był człowiekiem dobrym i mądrym, a to się trafia stosunkowo rzadko, i w tym wypadku się nie przytrafiło. Muszę powiedzieć że z większym zaufaniem można by powierzyć takiego pacjenta huculskim babom, które w najgorszym wypadku dają dobry lyk wódki, co pewno jest lepsze jak morfina i przedwczesne zabijanie człowieka, który chce jeszcze pobyć ze swoimi najblizssymi ${ }^{16}$.

Może ta myśl nie była zbyt obicktywna, ale racjonalne ziarno o humanistycznej podstawie medycyny ludowej bezsprzecznie tu istnicje.

Każdy szczegół życia wywoływał u pana Stanisława obraz miłej jego sercu Huculszczyzny, nawet w drobiazgach, jak w liście do Bazia Przybyłowskiego:

często o was myślę, gdy golę się aparatem przez Was podarowanym (...). Nie golę się zbyt często, chodzilem zarośnięty, aż Basia mnie zawstydziła, że żaden porządny Hucul nie nosi brody, którą z jakichś tam przyczyn zabobonnych nazywająa „kacapką", i jest zawsze ogolony ${ }^{17}$.

Tam na obczyźnie było właśnie coś, w myśli Vincenza, co jednoczyło wszystkich uchodźców:

Ostatecznie lączą nas tak dawne czasy i tak wiele, a w dodatku sprawy niedopowiedziane, nade wszystko taki kraj jak nasz. Zawsze wspominam, jak Gucio pierwszy raz przyjechal do Stobody. Zdaje mi się, że było to w maju, pogoda bardzo piękna, tak iż, zdaje mi się, owa wiosna jeszcze teraz nas cieszy i ogrzewa ${ }^{18}$.

Na szczególną uwagę zasługują nic tylko listy, które pisal Vincenz, ale i te, które dostawal. Na początku lat sześćdziesiątych, podczas „odwilży”, do Francji zaczynają docierać listy z ojczystego, huculskiego kraju. 20) grudnia 1965 roku w liście do Gustawa Goldberga Vincenz z właściwą mu mądrością pisze:

Dostaliśmy juz kilka listów z I Iuculszczyzny od naszych sąsiadów, które nas zobowiązıiją, a nawet podbijạą, swoją szczerością. Ostatecznie cóż na tej ziemi i przed opuszczeniem tego świata nam pozostaje, jeśli nie przyjaźń. I pamięc ${ }^{1 "}$.

\footnotetext{
1" St. Vincenz do Bazylego Rogowskiego. 8 listopada 1952 (sygn. 17 658/II).

1 St. Vincenz do Bazylego Przybylowskicgo. 3 grudnia 1950 (sygn. 17 658/1I).

${ }^{1 *}$ St. Vincenz do Gustawa Goldberga, 24 lutego 1966 (sygnt. 17 651/11).

"St. Vincenz do Gustawa Goldberga, 20 grudnia 1965 (sygn. 17 651/II).
} 
Listy z rodzinnych stron byly oczekiwanymi gośćmi w domu Vincenza, radośnie dzielił się on nowościami z rodziną Gertnerów:

Kochani Helı i Mirku!... dostaliśmy whaśnie dwa bardzo cickawe listy i w pierwszym rzẹdzie z Wami dzielimy się tą wiadomością. Jeden list z Żabiego, drugi z Bystrzeca. Ludzie bądź co bądź bardzo poczciwi, bo gdyby nie pomogli z wielkin wysiłkiem zabrać się nam stamtąd, to kto wie, co by bylo...20

Przed Bożym Narodzeniem 1966 roku Stanisław Vincenz otrzymal kolejny list z Ukrainy. Pisała do niego Wasylyna Czornysz, która przed wojną pracowala jako kucharka w domu Vincenzów. List ten jest wyjątkowy tak pod względem zawartości, jak i formy. Prosta i juz starsza kobieta, słabo widząca, poprosila młodszą krewną, by napisala za nią list do ludzi, których bardzo kochała i szanowała, którzy na zawsze zostali w jej pamięci. Na papier padly nie po prostu slowa, ale stowa ułożone w kołonnykę i poświęcone rodzinie Vincenzów. List ten jest tak ciekawy, że warto zacytować jego część w języku oruginału:

\section{Stan'a Isusu Chrystu!}

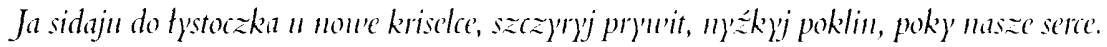

Unedilu raneseńko, szcze' ne zijszto sonce, jak prytetiu' sotou'ejko pid moje wikonce. Jak prytetiu' sotoucejko, poczau'szczebetaty, ja my sita ustau'aty do Was tyst pysaty. (...) Bażaju Wam, ditiam waszy'm, zdorou'ja ta sy't', usioho szczastia sim'ji Waszij, szczob u' garazdi ży't'. Kilka rokin' promymuto, jak ja Was ne baczu, ta tak tuzu ja za Wamy, czasom $i$ zaptaczu. Du̇̇e żatujut' za IWamy' i Hasze suside. (...)

I za szczo Was ludy' tychi sytoju zabraty? Czz' za te, szczo Wy tha zemli szczyro pracinu'aty? Czy za te, szczo Wy szczodemno Gospoda btagaty? Wy lubyty naszi gory' i btyżnoho su'oho, ditytysia dobrom surojim, ne robyty ztoho. A W', Pany naszi myli, "gory u'ertajte; a pro mene staru balu IV' ne zabuu'ajte. Szczebetata sira ptaszka, siła na ganoczck, az teper ja posptaju do Paniu' fystoczek. Zaszczebctau' sotou'cjko w' tuzi "dibrou'y, teper kinczu uktadaty, dhocen " rozmou'i.

Dalej Wasyłyna szczerze dziękuje za pomoc i dokładnie opowiada o nowościach ze wsi, a pragnąc jakoś się odwdzięczyć, pisze:

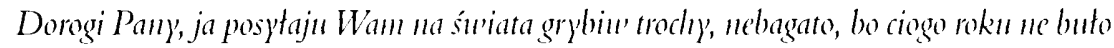
"rożaju na gryly.

A na zakończenie Wasyłyna zıów „składa”:

21" St. Vincenz do rodziny Gertncrów. 15 grudnia 1965 (sygn. 17 651/11). 
Oj, kuu'ata zozuteczka, ta kujut', ta kujut'. Sktadit' gubk'y' czerez tystok, naj sia pocitujut'. Bun'ajte zdorou'i. Wasza Wasy'tya't.

Wieści od Wasyłyny docieraty do rodziny Vincenzów także po śmierci samego pana Stanisława. Irena Vincenz w 1973 roku pisała do swej dawnej przyjaciółki z czasów pobytu na Iuculszczyźnie, Zofii Hertz, o losie Wasyłyny:

Pytasz o kontakt z krajem. Dostaję listy, nawet dość często, a także wizyty od czasu do czasu (...). Otrzymuję też listy z Żabiego, z Bystrzeca, tj. ze „związku sowieckiego", z Czerniowiec, ze Stanisławowa (obecnie Iwano-Frankiwsk), ze Lwowa. Kilka dni temu dostalam list i fotografię: wiadomość, że Wasylyna, nasza kucharka z Bystrzeca, umarła; fotografia - Wasyłyna w trumnie z wielkim drewnianym krzyżem na piersi. Jej rodzina przystala trzy fotografie: dla mnie, dla Basi i Jędrka.

O przyjaznych, rodzinnych stosunkach, które panowały w przeszłości między prostą wieśniaczką a całą rodziną Vincenzów, świadczą następne linijki tegoż listu:

Dzieci Jędrka znaja wszystkie bajki huculskie, jakie Wasyłyna jemu i Basi opowiadała, a także wszystkie „prawdziwe” historie o wilkach, niedźwiedziach, czortach - które Wasyłyna na wlasne oczy widziała - o Leśnych, Nimfach wodnych i Wilkolakach, itd., itd., itd ${ }^{22}$.

Ten epizod jest świetnym dowodem, z jakiego źródla talentu i mądrości ludowej mógł korzystać uważny słuchacz. którym byl Stanislaw Vincenz, zbierając materiały do swego opus vitue.

Listy z Ojczyzny były dla Vincenza nadzwyczaj ważne, co podkreśla on w liście do dawnego sąsiada z Krzyworówni, inżyniera Prokopiwa, który w tym czasie mieszkal w Samborze (na Ukrainie):

Oczekuję gorąco i niecierpliwie wiadomości, pozdrawiam Państwa serdecznie, a o ile możności także Rodaków ze Słobody, z Rungur, z Pieczyniżyna i z Markówki, Doboszowego miejsca, za którym nieustannie tęsknię. Kiedy na wiosnę bukowinki zaczną się rozwijać, trudno wytrzymać, i chce się iść piechotą prosto na Dubowy Lis, na Waratyki, na Kniażyj i na Rokietę... ${ }^{23}$

\footnotetext{
${ }^{21}$ Wasylyna Czornysz do St. Vincenza, 13 grudnia 1966 (sygni. 17 619/11).

"2 Irena Vincenz do Zofii Hertz. 15 kwietnia 1973 (sygn. 17 7(1)2/1I).

${ }_{23}^{23}$ St. Vincenz do Prokopiwa, 19 stycznia 1966 (sygn. 17 65்/11).
} 
Wydaje się, że samo to wyliczanie, wypowiadanie ,na głos” nazw ulubionych huculskich miejscowości sprawia niewymowną radość i uciechę pisarzowi.

Prawda, niektóre listy przynoszą nie zawsze przyjemne nowiny, choćby już wspomniany list Wasylyny Czornysz, i to jest bolesne dla pana Stanisława:

Dostajemy w dalszym ciągu ciekawe listy z Krzyworówni i Bystrzeca. Nasza shuzą̧ca Wasyłyna ułożyła śpiewankę, w której opisıje, jakie tam są zmiany (...). Lasy wyrąbane, tak że z miejsca, gdzie stal nasz dom, teraz widać aż na Maryszewską. Wszędzie porobiono drogi i jadą autobusy. Ubrania dawnego nie noszą, zamiast ślicznie wyszywanych koszul i serdaków jakieś obrzydlistwa sowieckiej mody ${ }^{24}$.

Pisarz odczuwał, że elementy cywilizacji, wprowadzane nie zawsze w sposób rozummy i umiarkowany, skazują ten niepowtarzalny huculski świat na zagładę, na zatratę autentyczności.

Vincenz bardzo chcial odwiedzić Ojczyznę, ale wahał się, czy to spotkanie nie będzie zbyt bolesne. List do Gustawa Goldberga z 1948 roku pełen jest dranatycznych rozmyślań:

Obrazy miejsc znajomych, krajobrazy ulic i domów wraz z nastrojami i otoczami tylu ludzi blizszych i dalszych, zniszczonych przez wojnę i przez okrucieństwo, nie opuszczają mnie. Właśnie nie miałbyn gustu pokazać się, a raczej stapić nogą na zicmi Stobody, Kołomyi, Stanisławowa czy Lwowa. Wszędzie śmierć, to mniejsza, ale wszędzie podeptanie czlowieczeństwa i bezsens tych niezliczonych śmierci, a przez to i życia. Jakiegoż wysitku potrzeba i jakich ofiar, jakich przysiąg i ich dotrzymania, aby świat odzyskał sens, który jest nadal, ale który zadeptano tak bezbożnie, jak tylko czlowiek potrafi? ${ }^{25}$

Wlasne doświadczenie i ciężkie lata wojny, przeżyte na emigracji, dawały pisarzowi bogaty material dla takich rozmyślań.

W 1966 roku Vincenz otrzymał od inżyniera Prokopiwa zaproszenie do odwiedzenia Huculszczyzny. W odpowiedzi napisał:

Wzruszyło mnie niesłychanie Pańskie zaproszenie, i patrzę w przyszłość prawie jak w obraz nityczny, iz miałbym zobaczyć bukowinki i Słobodę ${ }^{26}$.

\footnotetext{
${ }^{24}$ St. Vincenz do rodziny Gertnerów. 8 stycznia 1967 (sygn. $176,51 / 11$ ).

${ }^{25}$ St. Vincenz do Gustawa (roldberga, 14 czerwea 1948 (sygn. 17 65̄l/1I).

${ }^{2 t}$ St. Vincenz do Prokopiwa. 23 marca 1966 (sygn. 17 658/II).
} 
Ale te marzenia nie mogły się spełnić z powodu pogorszenia się stanu zdrowia pisarza. W liście z 13 września 1967 rokı do inżyniera Prokopiwa napisze on:

Niestety, i w tym roku, jak Pan widzi, nasza jazda do Słobody nie składa się. Natomiast sądzę, że moje zdrowie się poprawi, na razie jazda niemożliwa, ze względu na stan mego zdrowia ${ }^{27}$.

W 1961 rokı w Monachium Stanisław Vincenz występował ze swymi wspomnieniami o Huculszczyźnie i czytał urywki z Połoniny' przed grupą ukraińskich emigrantów. Słuchacze — byli krajanie pisarza - napiszą do niego list zbiorowy z podziękowaniami. Marta Zajaczkiwśka doda do tego wzruszające wsponnnienie z pobytu w domı Vincenza w Karpatach:

WSzanowni Państwo na pewno sobie mnie nie przypominacie, ale pobyt w Waszym domu pozostal dla muie niezatartym wspomnieniem. Bylo to chyba w latach trzydziestych. Nasza grupa turystów pod przewodem prokuratora I Iryhorija Onufrenki (ze Stanisławowa) po drodze ze Szpyci na Popa Iwana została ogarnięta przez burzę. Nie mogliśnny dojść do zamierzonego celı, i prokurator Onufrenko zaprowadził nas do Waszego domu, znanego z gościnności (na drzwiach napis: „Bądź uśmiechnięty!” zmusił nasze kwaśne, zmęczone twarze do naprawdę radosnego uśmiechu), gdzie znaleźliśmy schronienie i ochronę. Przemokłym do nitki pozwolił nam Pan osuszyć rzeczy i nakarmił głodnych. Z wdzięcznością i podziękowaniem, i z jeszcze milszym wspomnieniem opuściliśmy Wasz dom następnego dnia, udając się na zamierzoną wędrówkę. Proszę więc przyjąc tych kilka linijek wspomnienia o Was, Szanowni i Drodzy Państwo, do garści naszych wspomnień o swej drogiej, nigdy niezapomnianej I luculszczyźnie ${ }^{28}$.

Oksana Duczymińska, córka dawnej przyjaciółki Vincenzów, ukraińskiej pisarki Olgi Duczymińskiej, dopisze:

Cieszę się, że nie zapomina Pan naszej Huculszczyzny,

Iryna Kozak, W. Koroluk, Olga Pełenśka - po prostu podpiszą ten list. Mychajło Zygbon doda jeszcze od siebie:

Jeszcze jeden miłośnik Huculszczyzny i wszystkich, którzy ją kochają.

\footnotetext{
2- St. Vincenz do Prokopiwa, 13 wrzéśnia 1967 (sygn. 17 658/II).

${ }^{2 \star}$ List przedstawicieli ukraińskiej Wspólnoty z Monachium (po polsku), 27 września 1961 (sygnı. 17 647/II).
} 
Ten list byl jakby swoistą utraconą częścią z ogniwa życia, w której odczuwanny wyraźnie tęsknotę za zienią ojczystą, miejscem szczęśliwych lat dzieciństwa i młodości, tak dla autorów listu, jak i dla adresata.

W roku 1958 Stanisław Vincenz otrzymal prezent na swoje siedemdziesiąte urodziny. Był to album gratulacyjny z pozdrowieniami od przyjaciół z różnych krajów i różnych narodowości, w języku niemieckim, angielskim, włoskim, ukrainskim, polskim, francuskim. Nie zabrakło w nim i ,nuty huculskiej”. Dawny przyjaciel Jan Białostocki namalowal domek Stanisława Vincenza w Bystrzecu, który byl dla rodziny Vincenzów czymś więcej aniżeli zwykłe pomieszkanie. Tu spędziła rodzina Vincenzów może najszczęśliwsze lata swego życia. Tu Vincenz przyjimował gości z calego świata ${ }^{29}$.

Do tego malunku był dolączony wzruszający list:

Na Pański jubileusz of iaruję Panu to wspomnienie o Bystrzecu. Chcialbym, aby bylo to zarazem wspomnienie o dobrych latach bystrzeckich, o konkursach na znajomość geografii Grecji, o 35. symfonii Mozarta i o tym wszystkim, co Panı zawdzięczam. Życzę Panu dobrego zdrowia i wielı dalszych lat owocnej i twórczej pracy ${ }^{30}$.

Dawna przyjaciólka Stanisława Vincenza jeszcze z przedwojennych czasów, Mirrha Holzapfel-Hausner, wpisała do tegoż albumu wlasny utwór z dedykacją:

Kolęda huculskiej zazuli Stanisławowi Vincenzowi na 70 urodziny 30 XI 1958.

Ten utwór był stylizowany na pieśí ludową I Incułów i jak najbardzicj odpowiadał gustom solenizanta:
Zakowata zazuleńka tej popid hajowi,
A komu ta śpiewanoczka? Panu Doktorowi!
"Postuchajcie, dobri lude, tojej wierchowiny,
Oj, naszemu Doktorowi kwiatną urodziny!
Siedemdziesiąt lat ma dzisiaj, wiek wielkiej mądrości;
Lećże do niego daleko, z krainy mlodości,

\footnotetext{
${ }^{24}$ Jeanne Hersch wspominala dom w' Bystrzecu: „Maly domek z kanienia odwiedzali nie tylko wieśniacy. Przybywali tu uczeni. myślicicli, pisarze, poeci, artyści — z calego świata. Vincenz i pani Irena przyjmowali ich. jak mogli najlepicj. ale w miarę swych możliwości. Jeśli byla tylko mamalyga, jadlo siç mamalygę.

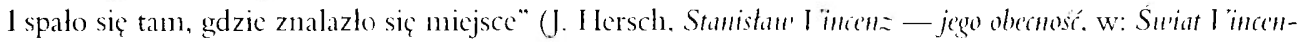
za.... op. cit.. s. 37 .

31) Album gratulacyjny na 7(), urodziny Vincenza. Materialy archiwum Stanistawa i Ireny Vincenzów w Dziale Rękopisów Bibliotcki Zakładu Narodowego inn. Ossolińskich we Wrockawiu (sygn. 17 270/II, s. 199-2(1).
} 
Oj, wiatroczku! Poshuchujesz ptaszce wierchowiny,

Nieś na plecach ku Szwajcarii Stascy połoniny!

Nieś jak piorum ich do brata śpiewaka sławnego!

Nieśże mędrcy starowieku wnet do progu jego!

Wiatr posłuszny zazuleczce, toż przynióst - gazdowie:

„Oj, Stasyno myłeseńki, daj Boże zdorowie!” Gazdowe i gazdynie:

„Daj Ci Boże szczęście wielkie, Ty nasz bracie miły!

Masz ty w sercu, masz Ty w duchu czarodziejskie siły!

My, gazdowie starowieku, o których ty śpiewał,

Przyszli z wiatrem oj, z daleka, gdzie dawnoś nie bywal,

Dziękujem Ci, Ty nasz druhu, oj, całym serdeńkiem,

Żeś Ty pisał o nas książkę piórem zołoteńkim,

Żeś o naszej wierchowinie śpiewał śpiewanoczku!

Toj nawiki bude żyty, Stasyno synoczku!

Toj nawiki bude żyty! Nigdy już nie minie

W sercach, w myślach dobrych lıdzi wieść o wierchowinie!"

Daj Boże! 31

Wszystko powiedziane wyżej świadczy o tym, że wielowymiarowy obraz Huculszczyzny w epistolografii Vincenza był jak gdyby hasłem dla wtajemniczonych, kluczem, albo raczej ogniwem lańcucha, jednoczącym rodaków na obczyźnie, pomagał im nie zagubić się w nowym środowisku, przypominał o konieczności zachowania tradycji i przekazania ich następnym pokoleniom. Staje się zrozumiałe, że w warunkach emigracji, kiedy korespondenci nie widzieli się długie lata, właśnie listy pozostawały jedyną możliwością podtrzymywania stosunków przyjaciclskich, zezwalały utrzymać w pamięci wspomnienia o swych korzeniach i nie zagubić siç ,na czużyni”. A tematem integracyjnym korespondencji Stanislawa staje się obraz Huculszczyzny.

W niewielkim artykule nie można rozpatrzyć wnikliwie wszystkich cech obrazu Huculszczyzny, który bỵl ważnym stylistycznym elementem, jak również tematem charakterystycznym korespondencji Stanisława Vincenza - tak że mógł on z ręką na sercu napisać w 1969 roku w przedmowie do druku fragmentów powieści $N a$ u'ysokiéj połonimie w ukraińskim czasopiśmie „Żowteń": „Jestem dzicckiem kraju huculskiego...”??

\footnotetext{
31. Album gratulacyjny.... s. 2(0)-201. Whaśnic Mirrha Holzapfel przclożyła kilka fragmentów z Na u’ysokicj potonimie dla szwajcarskicgo pisma ..Wandlung".

${ }^{32}$ Kopia przedmowy (w języku polskim) do pisma „Żowteń” z archiwum Vincenza w Dziale Rękopisów Bibliotcki Zakladu Narodowego im. Ossolińskich we Wroclawiu (sygn. 17 651/1I).
} 